\title{
What Else to Pay Attention in Terms of Bone Health Other than Osteoarthritis among Candidates Undergoing Total Knee Replacement: Observations in a Subset of Indian Population
}

\author{
Amol Prabhakar Pandey ${ }^{1}$ Sonam Dubey ${ }^{20} \quad$ Kavita Sharma $^{3} \quad$ Pankaj Soni $^{1}$ \\ ${ }^{1}$ Department of Orthopaedics, Max Super Speciality Hospital, Saket, \\ New Delhi, India \\ 2 Department of Pathology, Government Medical College Shahdol, \\ Madhya Pradesh, India \\ Address for correspondence Sonam Dubey, MBBS, MD, F- 203, F-Type \\ Building, Government Medical College Shahdol Campus, Shahdol, \\ Madhya Pradesh 484001, India \\ (e-mail: sonamdubeyrewa@gmail.com).
}

${ }^{3}$ Department of Pathology, Sardar Patel Medical College Bikaner, Rajasthan, India

Int J Recent Surg Med Sci 2022;8:89-94

\begin{abstract}
Keywords

- arthroplasty

- dual-energy X-ray absorptiometry

- osteoarthritis

- osteoporosis

- parathyroid hormone

Background Earlier it was thought that osteoarthritis and osteoporosis were mutually exclusive but many studies now prove that these diseases coexist. This study was undertaken to assess the bone health in terms of mineral density and other markers among patients undergoing total knee replacement due to osteoarthritis.

Methods A total of 100 patients with advanced osteoarthritis undergoing total knee replacement and satisfying inclusion and exclusion criteria were selected. Detailed social, medical, personal, and family history was recorded. All participants underwent for dual-energy X-ray absorptiometry scan (spine and both hips), X-rays (both knees and pelvis), Western Ontario and McMaster Universities osteoarthritis index (WOMAC) scoring, and serum levels of vitamin D, calcium, phosphorus, alkaline phosphatase, and Parathyroid hormone (PTH). Data collected and analyzed.

Results In total, $87 \%$ of total participants were females. Mean values for age, height, weight, serum vitamin D3, serum PTH, serum calcium, serum phosphorus, serum alkaline phosphatase, WOMAC score, and bone mineral density (BMD) score (T-score) were 65.35 years, $160.15 \mathrm{~cm}, 69.37 \mathrm{~kg}, 26.91 \mathrm{ng} / \mathrm{mL}, 48.02 \mathrm{pg} / \mathrm{mL}, 9.01 \mathrm{mg} / \mathrm{mL}$, $3.40 \mathrm{ng} / \mathrm{mL}, 57.91 \mathrm{IU} / \mathrm{L}, 56.32$, and -1.16 , respectively.

Conclusion Osteopenia and osteoporosis seem prevalent in the Indian population with advanced knee osteoarthritis. Our findings do not support the hypothesis of inverse relation between osteoarthritis and lower BMD. The study reflected poorer bone health and lesser average age for Indian patients undergoing total knee replacement.
\end{abstract}

DOI https://doi.org/ 10.1055/s-0041-1742142. ISSN 2455-7420.
(C) 2022. Medical and Surgical Update Society. All rights reserved. This is an open access article published by Thieme under the terms of the Creative Commons Attribution-NonDerivative-NonCommercial-License, permitting copying and reproduction so long as the original work is given appropriate credit. Contents may not be used for commercial purposes, or adapted, remixed, transformed or built upon. (https://creativecommons.org/ licenses/by-nc-nd/4.0/)

Thieme Medical and Scientific Publishers Pvt. Ltd., A-12, 2nd Floor, Sector 2, Noida-201301 UP, India 


\section{Introduction}

Osteoarthritis (OA) is the most common form of arthritis, and the commonest cause of disability among adults. ${ }^{1,2}$ Knee OA tends to impose great burden to populations, as the resulting pain and stiffness often lead to significant disability requiring total knee replacement. ${ }^{3} \mathrm{OA}$ of the knee is more common in women as well as in elderlies, so age and sex are both risk factors for development of OA. ${ }^{2-4}$ Age and female sex are also high risk factors for development of osteoporosis. ${ }^{5-7}$

In most previous studies, it was indicated that these two diseases were inversely related. ${ }^{8,9}$ The prevalence of osteoporosis in patients undergoing hip and knee arthroplasty was found to be low. Hip and knee arthroplasty patients had higher bone mineral density (BMD) than an age-matched general population. ${ }^{10}$ But other studies do not support their mutually exclusive nature. ${ }^{11}$

Orthopaedicians while taking care of advanced OA might show little interest in osteoporosis care. The high costs of medication and lack of awareness among physicians and patients about coexistent diseases could be the most important barriers. $^{12,13}$ The role of antiresorptive drugs (bisphosphonates) in pain management and periprosthetic bone loss prevention indirectly supports osteoporosis as a contributor in postoperative pain (and implant loosening) in arthroplasty. ${ }^{14}$

A retrospective review of 723 patients undergoing surgery at an orthopedic hospital revealed that $40 \%$ of patients were vitamin D-deficient. ${ }^{15}$ Similarly, in a large prospective study, those with the lowest vitamin D3 levels at baseline had the most rapid progression to knee $\mathrm{OA} .^{16}$

Interplay of 25-hydroxyvitamin D3 (vitamin D), parathyroid hormone $(\mathrm{PTH})$, calcium, phosphorus, alkaline phosphatase, etc. is responsible for bone health and these are recorded simultaneously here along with BMD that is rare in existing related Indian studies.

Our primary objective was to determine prevalence of poor bone health in patients with severe OA undergoing total knee replacement in a subset of Indian population. A secondary objective was to compare the trend with that described for populations abroad.

\section{Methods}

\section{Study design}

Hospital-based, cross-sectional, observational, and nonrandomized study.

A total of 100 patients during a 5-month span with advanced OA undergoing total knee replacement at Max Super Specialty Hospital, Saket, New Delhi, India were included in this study: all of them satisfied the inclusion and exclusion criteria.

Using the prevalence of poor bone health (osteoporosis and osteopenia) as $58.6 \%$, which was reported by Domingues et al, we calculated the sample size as 92 with the following formula:

$$
\frac{z \alpha / 2 \pi(1-\pi)}{L^{2}}
$$

where $\pi$ is equal to 0.586 , and we took $L=0.10$ as the margin of error. The confidence level is $95 \%$, which gives $z_{\alpha / 2}=1.96$.

\section{Inclusion Criteria}

- All patients with advanced knee OA undergoing total knee replacement.

- Age 50 to 80 years.

\section{Exclusion Criteria}

- History of treatment for osteoporosis.

- Primary hyperparathyroidism.

- History suggestive of malabsorption of vitamin D.

- Patients taking any medication(s) that could adversely affect bone metabolism.

- History of any renal disease contributing impaired hydroxylation of $25(\mathrm{OH})$ vitamin $\mathrm{D}$ to 1,25 -dihydroxyvitamin D.

- Secondary osteoporosis due to prolonged glucocorticoid intake or significant hepatic or thyroid dysfunction.

After clearance from institutional ethical and scientific committees, we proceeded with the study.

All patients were subjected to dual-energy X-ray absorptiometry (DXA) scan (of both hips and spine). All the values were noted in the form of T-score and World Health Organization guidelines were followed for categorizing as osteoporosis $(<-2.5)$, osteopenia $(-1$ to -2.5$)$, and normal $(>-1)$. X-rays (both knees-standing anteroposterior and lateral views-and pelvis with both hips-anteroposterior view) were recorded. X-rays interpreted as Lawrence and Kellgren type III were considered as advanced OA. Opinions were taken from two independent radiologists regarding condition of bone at the two different sites (spine and hips). Additionally, serum levels of vitamin D, phosphorus, alkaline phosphatase, and PTH were performed along with other routine preoperative workups. Activity levels of the patient were recorded using the Western Ontario and McMaster Universities osteoarthritis index (WOMAC) scoring system. A detailed social and medical history including features of osteoporosis (h/o fragility fractures), dietary habits, intake of medications and supplements, personal history, and family history (fractures, loss of height, bone pains, etc.) were also recorded.

The DXA machine used was common to all (Hologic DXA system, United States).

Serum vitamin D levels were measured by the chemiluminescence method, serum calcium by the Arsenazo III method, alkaline phosphatase by the 2-amino-2-methylpropanol buffer method, serum phosphorus by phosphomolybdate method, and serum PTH was measured via the intact PTH method.

Reference values considered are shown in -Table 1 .

\section{Statistical Analysis}

Data were analyzed by correlating the following findings:

- Serum levels of vitamin D3.

- BMD (T-score) value.

- Serum alkaline phosphatase and PTH.

- Serum calcium and phosphorus levels.

These correlations compared by Fisher's Z transformation test with values reported in previous literature. 
Table 1 Reference values considered for laboratory parameters

\begin{tabular}{|l|l|l|l|l|}
\hline S.N. & Parameter & Reference range & CF \\
\cline { 3 - 5 } & & Conventional unit & SI unit & 2.5 \\
\hline 1. & Serum vitamin D3 & $30.0-100 \mathrm{ng} / \mathrm{mL}$ & $75-250 \mathrm{nmol} / \mathrm{L}$ & 0.2495 \\
\hline 2. & Serum calcium & $8.8-10.2 \mathrm{mg} / \mathrm{dL}$ & $2.19-2.54 \mathrm{mmol} / \mathrm{L}$ & 0.01667 \\
\hline 3. & Serum alkaline phosphatase & $32.0-91 \mathrm{IU} / \mathrm{L}$ & $0.53-1.52 \mu \mathrm{kat} / \mathrm{L}$ & 0.3229 \\
\hline 4. & Serum phosphorus & $2.3-4.0 \mathrm{mg} / \mathrm{dL}$ & $0.74-1.29 \mathrm{mmol} / \mathrm{L}$ & $12-88 \mathrm{ng} / \mathrm{L}$ \\
\hline 5. & Serum PTH & $12-88 \mathrm{pg} / \mathrm{mL}$ & 12 & 1 \\
\hline
\end{tabular}

Abbreviations: CF, conversion factor, from conventional unit to SI unit; PTH, parathyroid hormone.

In addition, average T-scores in our patients were compared with previous T-scores by Student's $t$-test.

The Kruskal-Wallis test and analysis of variance (ANOVA) were also used, wherever applicable.

\section{Results}

A total of 100 patients were included in the final result analysis. The following observations and results were found.

- 87 (87\%) were female, and 13 male.

- Mean value and observed range for various parameters (-Table 2).

\section{Right Hip}

A total of 26 patients had normal bone, 59 had osteopenia, and 15 patients had osteoporosis in the right hip.

Of the 26 patients with normal BMD, 21 were female and 5 were male. This cohort's average age was $61.85 \pm 8.64$ (range, 51-80 years); average height $160 \pm 6.82$ (range, $147-174 \mathrm{~cm}$ ), and mean weight was $71.81 \pm 6.78$ (range, $59-85 \mathrm{~kg}$ ). Serum

Table 2 Mean value and observed range for various parameters

\begin{tabular}{|l|l|l|}
\hline $\begin{array}{l}\text { Parameters } \\
\text { (with unit of measure) }\end{array}$ & Mean value & Range \\
\hline Age $(\mathrm{y})$ & $65.35 \pm 8.28$ & $50-80$ \\
\hline Height $(\mathrm{cm})$ & $160.15 \pm 7.14$ & $147-178$ \\
\hline Weight $(\mathrm{kg})$ & $69.37 \pm 7.59$ & $52-85$ \\
\hline Serum vitamin D3 $(\mathrm{ng} / \mathrm{mL})$ & $26.91 \pm 16.62$ & $5-78$ \\
\hline Serum PTH $(\mathrm{pg} / \mathrm{mL})$ & $48.02 \pm 8.68$ & $20.3-76.1$ \\
\hline Serum calcium $(\mathrm{mg} / \mathrm{dL})$ & $9.01 \pm 0.46$ & $7.9-10.5$ \\
\hline Serum phosphate $(\mathrm{mg} / \mathrm{dL})$ & $3.40 \pm 00.45$ & $1.9-4.7$ \\
\hline $\begin{array}{l}\text { Serum alkaline } \\
\text { phosphatase }(\mathrm{IU} / \mathrm{L})\end{array}$ & $57.91 \pm 9.25$ & $42-98$ \\
\hline WOMAC score & $56.32 \pm 7.81$ & $34-76$ \\
\hline $\begin{array}{l}\text { BMD score (T-scores) } \\
\text { for the right hip }\end{array}$ & $-1.68 \pm 1.11$ & -4.0 to 1.4 \\
\hline $\begin{array}{l}\text { BMD score (T-scores) } \\
\text { for the left hip }\end{array}$ & $-1.457 \pm 1.1$ & $-4.9-1.8$ \\
\hline $\begin{array}{l}\text { Overall BMD } \\
\text { score (T-score) }\end{array}$ & $-1.16 \pm 1.7$ & $4.7-1.8$ \\
\hline
\end{tabular}

Abbreviations: BMD, bone mineral density; PTH, parathyroid hormone; WOMAC, Western Ontario and McMaster Universities osteoarthritis index. vitamin D3 levels averaged $39.02 \pm 19.11$ (range, $10-78 \mathrm{ng} / \mathrm{mL}$ ). The mean serum PTH level was $47.34 \pm 6.31$ (range, 33.9-58.0 $\mathrm{pg} / \mathrm{mL}$ ), mean serum calcium $9.08 \pm 0.53$ (range, 7.9$10.5 \mathrm{mg} / \mathrm{dL}$ ), mean serum phosphorous $3.37 \pm 0.53$ (range, $1.9-4.7 \mathrm{mg} / \mathrm{dL}$ ), and the mean value for serum alkaline phosphatase was $58.65 \pm 9.43$ (range, $42-80 \mathrm{IU} / \mathrm{L}$ ).

Of the 59 patients diagnosed as osteopenic, 52 were female and 7 male. The average age of this cohort was $65.97 \pm 7.76$ (range, 50-80 years), mean height $160.03 \pm 7.64$ (range, 143$178 \mathrm{~cm}$ ), and mean weight was $69.70 \pm 7.47$ (range, $52-85 \mathrm{~kg}$ ). Mean serum vitamin D3 level was $23.20 \pm 12.58$ (range, 5.0$64.2 \mathrm{ng} / \mathrm{mL}$ ), mean serum PTH $47.76 \pm 9.85$ (range, 20.3-76.1 $\mathrm{pg} / \mathrm{mL}$ ), mean serum calcium $9.05 \pm 0.43$ (range, 8.2$10.3 \mathrm{mg} / \mathrm{dL}$ ), mean serum phosphorous $3.41 \pm 0.44$ (range, $2.1-4.7 \mathrm{mg} / \mathrm{dL}$ ), and average serum alkaline phosphatase level was $58.00 \pm 9.39$ (range, $45-98 \mathrm{IU} / \mathrm{L}$ ).

In total, 15 patients presented with osteoporosis, of which 14 patients were female and 1 was male. This cohort's average age was $69.00 \pm 7.95$ (range, $57-78$ years), mean height was $160.16 \pm 5.98$ (range, $52-74 \mathrm{~cm}$ ), and mean weight was $63.73 \pm 6.96$ (range, $52-74 \mathrm{~kg}$ ). As a group, the average serum vitamin D3 level was $20.48 \pm 16.41$ (range, 5$49.7 \mathrm{ng} / \mathrm{mL}$ ), mean serum PTH level $50.21 \pm 7.31$ (range, 34.0-57.1 pg/mL), mean serum calcium level $9.02 \pm 0.45$ (range, $8.0-10.3 \mathrm{mg} / \mathrm{dL}$ ), mean serum phosphorous $3.36 \pm 0.48$ (range, $2.3-4.2 \mathrm{mg} / \mathrm{dL}$ ), and average serum alkaline phosphatase level was $56.27 \pm 9.06$ (range, $45-87 \mathrm{IU} / \mathrm{L}$ ).

For the right hip, we found that age was significantly associated with reduction in T-scores (on DXA scan) (ANOVA test: $p$-value $=0.018(<0.05))$. We can therefore state that as the age progresses, prevalence of osteoporosis increases.

Similarly, on comparing all three groups (i.e., normal, osteopenia, and osteoporotic groups), the average weight was found to be decreasing ( $p$-value highly significant, $p$ value $=0.003(<0.05)$ ). Therefore, we can say that patients with lower weight had more osteopenia and osteoporosis.

The WOMAC scoring in these groups showed the following findings: osteopenic and osteoporotic had higher scores, which reflects the severity of disease in the form of disability. This also was found to be highly significant (with $p$-values $=0.001(<0.05))$.

\section{Left Hip}

A total of 34 patients had normal T-values, 48 had osteopenia, and 18 osteoporosis. 
Out of the 34 patients with normal bone, 25 were female and 9 were male. The mean age was $63.03 \pm 8.17$ (range, 50 80 years), mean height $161.50 \pm 7.75$ (range, $147-178 \mathrm{~cm}$ ), and mean weight was $71.82 \pm 7.73$ (range, $52-85 \mathrm{~kg}$ ). The mean value for serum vitamin D3 was $34.78 \pm 18.98$ (range, 10-78 ng/mL), mean PTH 48.35 \pm 9.19 (range, 23-76.1 $\mathrm{pg} / \mathrm{mL}$ ), average serum calcium $9.07 \pm 0.53$ (range, 7.9$10.5 \mathrm{mg} / \mathrm{dL}$ ), average phosphorus $3.39 \pm 0.56$ (range, 1.9 $4.7 \mathrm{mg} / \mathrm{dL}$ ), and mean alkaline phosphatase was $57.38 \pm 8.23$ (range, 42-87 IU/L).

Among the 48 patients with osteopenia, 45 were female and 3 were male. The mean age was $66.48 \pm 8.15$ (range, 50 80 years), mean height $158.74 \pm 7.03$ (range, $143-176 \mathrm{~cm}$ ), and mean weight was $69.34 \pm 7.27$ (range, $52-82 \mathrm{~kg}$ ). The mean serum vitamin D3 level was $23.42 \pm 13.34$ (range, 5$64.2 \mathrm{ng} / \mathrm{mL}$ ), mean serum PTH $47.54 \pm 8.29$ (range, 20.4-58.0 $\mathrm{pg} / \mathrm{mL}$ ), mean serum calcium $9.02 \pm 0.45$ (range, 8.0-10.3 $\mathrm{mg} / \mathrm{dL}$ ), mean serum phosphorus $3.44 \pm 0.40$ (range, 2.7$4.7 \mathrm{mg} / \mathrm{dL}$ ), and mean serum alkaline phosphatase was $59.10 \pm 10.50$ (range, 45-98 IU/L).

A total of 18 patients were diagnosed as osteoporosis, of which 17 were female and 1 was male. The average age for this group was $66.72 \pm 7.19$, average height $161.39 \pm 5.76$ (range, 150-170 cm), and average weight was $65.00 \pm 6.53$ (range, $54-74 \mathrm{~kg}$ ). The mean value of serum vitamin D3 was $21.34 \pm 15.03$ (range, $5-49.7 \mathrm{ng} / \mathrm{mL}$ ), mean serum PTH $48.67 \pm 9.13$ (range, $20.3-57.1 \mathrm{pg} / \mathrm{mL}$ ), mean serum calcium $8.89 \pm 0.36$ (range, $8.2-9.3 \mathrm{mg} / \mathrm{dL}$ ), mean serum phosphorus $3.27 \pm 0.43$ (range, $2.4-4.2 \mathrm{mg} / \mathrm{dL}$ ), and average serum alkaline phosphatase level was $55.73 \pm 7.19$ (range, 45-98 IU/L).

With increasing age, there should be poor bone health, but our results showed $p$-value $=0.132(>0.05)$, that is, for the left hip, when we took age as a factor, differences among the groups were not significant. The average weight decreased with deterioration of bone health, $p$-values $=0.009(<0.05)$, a highly significant value. Similarly, the WOMAC scores increased with the deterioration of bone health ( $p$-value $=0.000$, highly significant).

\section{Spine}

A total of 44 patients had a normal BMD, 31 patients showed osteopenia while 25 showed osteoporosis in the spine DXA scans.

Of the 44 patients showing normal DXA values, 35 were female and 9 male. The mean age was $65.2 \pm 8.64$ (range, 50 80 years), mean height $160.69 \pm 7.16$ (range, $143-176 \mathrm{~cm}$ ), and mean weight was $70.44 \pm 8.13$ (range, $52-85 \mathrm{~kg}$ ). Mean value for serum vitamin D3 was $26.70 \pm 16.33$ (range, 5$68 \mathrm{ng} / \mathrm{mL}$ ), mean serum PTH $48.13 \pm 8.38$ (range, 23-76.1 $\mathrm{pg} / \mathrm{mL}$ ), mean serum calcium $9.04 \pm 0.50$ (range, 7.9-10.5 $\mathrm{mg} / \mathrm{dL}$ ), mean serum phosphorus $3.41 \pm 0.52$ (range, 1.9$4.7 \mathrm{mg} / \mathrm{dL}$ ), and mean serum alkaline phosphatase level was $58.65 \pm 10.13$ (range, 45-98 IU/L).

Of the 31 patients with osteopenia, 28 were female and 3 male. These included patients with an average age of $64 \pm 8.21$ (range, $50-80$ years), mean height of $159.16 \pm 7.90$ (range, $143-178 \mathrm{~cm}$ ), and mean weight of $69.37 \pm 7.22$ (range, $52-85 \mathrm{~kg}$ ). The mean value for serum vitamin D3 was $31.00 \pm 16.08$ (range, $8.2-10.0 \mathrm{ng} / \mathrm{mL}$ ), for serum phosphorous $3.36 \pm 0.42$ (range, $2.6-4.7 \mathrm{mg} / \mathrm{dL}$ ), for serum PTH $48.67 \pm 8.05$ (range, $26-78 \mathrm{pg} / \mathrm{mL}$ ), for serum calcium $8.98 \pm 0.46$ (range $8.2-10.0 \mathrm{mg} / \mathrm{dL}$ ), and for serum alkaline phosphatase was $58.16 \pm 8.44$ (range, 2.6-4.7 IU/L).

In total, 24 (96\%) of the 25 patients with osteoporosis were female while 1 (4\%) was male. The mean age was $67.20 \pm 8.39$ (range, 50-80 years), height $160.44 \pm 6.25$ (range, 147-170 cm), and weight was $67.44 \pm 6.99$ (range, $54-81 \mathrm{~kg}$ ). Average values are $22.20 \pm 15.03$ (range, 5-64.2 $\mathrm{ng} / \mathrm{mL}$ ) for serum vitamin $\mathrm{D} 3,47.03 \pm 10.12$ (range, 20.3$57.1 \mathrm{pg} / \mathrm{mL}$ ) for serum PTH, $8.98 \pm 0.41$ (range, 8.0-9.6 $\mathrm{mg} / \mathrm{dL}$ ) for calcium, $3.42 \pm 0.44$ (range, $2.3-4.2 \mathrm{mg} / \mathrm{dL}$ ) for serum phosphorus, and $56.40 \pm 8.74$ (range, $42-82 \mathrm{IU} / \mathrm{L}$ ) for serum alkaline phosphatase. The WOMAC scores averaged $59.68 \pm 7.81$ (range, 44-76) for this group.

\section{X-Ray Interpretation}

Unbiased, independent opinions of two radiologists were taken. Interpretations are presented in - Table 3.

On comparison, agreement of two radiologists about the condition of bone quality through X-rays is fair (measured by kappa test).

\section{Discussion}

This is probably the first study done in India to find out prevalence of poor bone health in an Indian population, and its correlation with the presence of OA. Indian female population is especially at high risk to develop osteoporosis compared with the Western population. Poorer nutrition than the Western population and less physical activity make more prone for development as well as for severity of osteoporosis.

Several community-based studies had presented evidence of an inverse relationship between osteoporosis and $\mathrm{OA}$. There are very few studies done to find out the relationship between advanced OA and osteoporosis. Bergink et al mentioned that patients having advanced OA knee have increased risk of incident vertebral and nonvertebral fractures. ${ }^{17}$ Pal et al also noted that $\mathrm{OA}$ is more prevalent in the female population as compared with their male counterpart. ${ }^{2}$ Age and early menopause in female are individual risk factors for developing osteoporosis. ${ }^{18}$ O'Connor also stated that women have more prevalence and severity of OA. ${ }^{19}$ Looker et al noted similar results in an American population. ${ }^{20}$ Older age is a significant risk factor for $\mathrm{OA} .^{21}$ These results are in concordance with our study.

Poor nutrition causes dietary deficiency of proteins and hence causes weak bone. ${ }^{22}$ Calcium intake in elderly is lesser and reduced absorption further lowers effective intake. Vitamin D deficiency is very common in elderlies ${ }^{23}$ and in the osteoporotic female, ${ }^{24}$ and is also associated with progression of OA. ${ }^{25}$ Therefore, vitamin D levels appear to be a contributing factor for both these diseases.

In the present study, 48 (48\%) patients had vitamin D3 deficiency and 12 (12\%) patients had insufficiency of vitamin D3, while 40 (40\%) patients had an adequate level. Ghosh 
Table 3 Interpretations of two radiologists for given DXA scan category

\begin{tabular}{|c|c|c|}
\hline DXA scan category & $\begin{array}{l}\text { X-ray } \\
\text { interpretation } \\
\text { by Radiologist I }\end{array}$ & $\begin{array}{l}\text { X-ray } \\
\text { interpretation } \\
\text { by Radiologist II }\end{array}$ \\
\hline \multicolumn{3}{|l|}{ For right hip } \\
\hline Normal, $n=26$ & $\begin{array}{l}25 \text { normal } \\
1 \text { osteoporotic }\end{array}$ & $\begin{array}{l}25 \text { normal } \\
1 \text { osteoporotic }\end{array}$ \\
\hline Osteopenia, $n=59$ & $\begin{array}{l}23 \text { normal } \\
28 \text { osteopenic } \\
8 \text { osteoporotic }\end{array}$ & $\begin{array}{l}23 \text { normal } \\
28 \text { osteopenic } \\
8 \text { osteoporotic }\end{array}$ \\
\hline Osteoporosis, $n=15$ & $\begin{array}{l}2 \text { normal } \\
13 \text { osteoporotic }\end{array}$ & $\begin{array}{l}2 \text { normal } \\
13 \text { osteoporotic }\end{array}$ \\
\hline \multicolumn{3}{|l|}{ For left hip } \\
\hline Normal, $n=34$ & $\begin{array}{l}30 \text { normal } \\
3 \text { osteopenic } \\
1 \text { osteoporotic }\end{array}$ & $\begin{array}{l}28 \text { normal } \\
5 \text { osteopenic } \\
1 \text { osteoporotic }\end{array}$ \\
\hline Osteopenia $n=48$ & $\begin{array}{l}17 \text { normal } \\
23 \text { osteopenic } \\
8 \text { osteoporotic }\end{array}$ & $\begin{array}{l}20 \text { normal } \\
21 \text { osteopenic } \\
7 \text { osteoporotic }\end{array}$ \\
\hline Osteoporosis, $n=18$ & $\begin{array}{l}3 \text { normal } \\
2 \text { osteopenic } \\
13 \text { osteoporotic }\end{array}$ & $\begin{array}{l}2 \text { normal } \\
5 \text { osteopenic } \\
11 \text { osteoporotic }\end{array}$ \\
\hline \multicolumn{3}{|l|}{ For spine } \\
\hline Normal, $n=44$ & $\begin{array}{l}37 \text { normal } \\
7 \text { osteopenic }\end{array}$ & $\begin{array}{l}39 \text { normal } \\
5 \text { osteopenic }\end{array}$ \\
\hline Osteopenia, $n=31$ & $\begin{array}{l}12 \text { normal } \\
19 \text { osteopenic }\end{array}$ & $\begin{array}{l}14 \text { normal } \\
17 \text { osteopenic }\end{array}$ \\
\hline Osteoporosis, $n=25$ & $\begin{array}{l}7 \text { osteopenic } \\
18 \text { osteoporotic }\end{array}$ & $\begin{array}{l}5 \text { normal } \\
20 \text { osteoporotic }\end{array}$ \\
\hline
\end{tabular}

Abbreviation: DXA, dual-energy X-ray absorptiometry.

et $\mathrm{al}^{26}$ found normal vitamin D3 value in $45.92 \%$ of his patients (comparable to our study), vitamin D3 insufficiency in $29.59 \%$ (lower in our study), while vitamin D3 deficiency in 24.49\% (higher in our study). Among the control group, $66.66 \%$ had normal serum vitamin D3, $13.89 \%$ had insufficiency, and $19.44 \%$ had deficiency indicating that patients with advanced OA have a higher prevalence of vitamin D deficiency than the normal population.

Breijawi et $\mathrm{al}^{27}$ reported in their study that $84.7 \%$ of the patients with OA had serum vitamin D3 levels lower than $30 \mathrm{ng} / \mathrm{mL}$. Jansen and Haddad found $24 \%$ prevalence of vitamin D deficiency in elderly patients scheduled for total knee replacement. ${ }^{28}$ Domingues et al found a very high (84.4\%) prevalence of inadequate vitamin $\mathrm{D}$ in patients undergoing total hip arthroplasty. ${ }^{29}$

Ghosh et $\mathrm{al}^{26}$ showed $18.37 \%$ of subjects in the study group and $19.44 \%$ of subjects in the control group had normal BMD: $32.65 \%$ cases and $58.3 \%$ controls were osteoporotic; $49.98 \%$ cases and $22.22 \%$ controls had osteopenia; in total $81.63 \%$ of cases and $80.55 \%$ of controls had BMDs less than 1 standard deviation below the mean for young healthy adults of the same sex, thus showing a significant correlation of BMD with age.

Chang et al have reported that $57.1 \%$ patients had osteopenia, $30.7 \%$ patients had osteoporosis, and $47.7 \%$ patients had osteopenia in the proximal femur, while $28.9 \%$ patients had osteoporosis of the lumbar spine. ${ }^{30}$ In the study done by Lingard et al, 24\% patients had osteopenia and 9\% patients had osteoporosis in lumbar spine; $36 \%$ patients had osteopenia and $8 \%$ had osteoporosis of the index proximal femur; and $31 \%$ patients had osteopenia and $6 \%$ patients had osteoporosis of the contralateral proximal femur. ${ }^{31}$

Labuda et al conducted a study to find out the prevalence of osteoporosis in joint arthroplasty patients, and found the prevalence of $26 \%$ of osteoporosis in prearthroplasty patients, and not unsurprisingly, higher rates in women. ${ }^{32}$

Domingues et al similarly found $20.7 \%$ prevalence of osteoporosis and $37.9 \%$ of osteopenia in patients undergoing total hip arthroplasty. ${ }^{29}$

We found very high values of WOMAC scores in right, left hip, and spine with osteopenia and osteoporosis in these groups. This indicates that presence of disability has a significant correlation with development of osteoporosis. Lingard et $\mathrm{al}^{31}$ also found high WOMAC scores in patients with $\mathrm{OA}$, which confirmed the presence of severe disease, but they found no significant difference in its prevalence between osteoporotic and nonosteoporotic groups, ${ }^{31}$ unlike our study. Chang et $\mathrm{a}^{30}$ concluded that poor functional status (determined by WOMAC and SF-36 scores) was related to poorer BMD status.

\section{Conclusion}

In our study, we found that patients undergoing total knee replacement for advanced OA had poor bone health, as seen by the high prevalence of vitamin D3 insufficiency (60\%), osteopenia, and osteoporosis in the hips (73\% for the right, $66 \%$ for the left) and spine (56\%). Osteopenia and osteoporosis seem prevalent in the Indian population with advanced knee OA.

\section{Limitations}

The age range (50-80 years) included in study is younger than that in the Western literature. The sample size of 100 is also less. Most patients belong to urban areas, therefore not the true representation of the target population and the control group was not assigned for the study.

Funding

None.

Conflict of Interest

None declared.

Acknowledgment

We are grateful to Dr. Jitendra Maheshwari and Dr. Rajiv Thukral for their constant support and guidance.

\section{References}

1 Murphy L, Helmick CG. The impact of osteoarthritis in the United States: a population-health perspective: a population-based review of the fourth most common cause of hospitalization in U.S. adults. Orthop Nurs 2012;31(02):85-91 
2 Pal CP, Singh P, Chaturvedi S, Pruthi KK, Vij A. Epidemiology of knee osteoarthritis in India and related factors. Indian J Orthop 2016;50(05):518-522

3 Litwic A, Edwards MH, Dennison EM, Cooper C. Epidemiology and burden of osteoarthritis. Br Med Bull 2013;105:185-199

4 Dixon T, Shaw M, Ebrahim S, Dieppe P. Trends in hip and knee joint replacement: socioeconomic inequalities and projections of need. Ann Rheum Dis 2004;63(07):825-830

5 Khadilkar AV, Mandlik RM. Epidemiology and treatment of osteoporosis in women: an Indian perspective. Int J Womens Health 2015;7:841-850

6 Burger H, de Laet CE, van Daele PL, et al. Risk factors for increased bone loss in an elderly population: the Rotterdam Study. Am J Epidemiol 1998;147(09):871-879

7 Cummings SR, Melton LJ. Epidemiology and outcomes of osteoporotic fractures. Lancet 2002;359(9319):1761-1767

8 Hart DJ, Mootoosamy I, Doyle DV, Spector TD. The relationship between osteoarthritis and osteoporosis in the general population: the Chingford Study. Ann Rheum Dis 1994;53(03):158-162

9 Moreschini O, Margheritini F, Albanese Ginammi E, Mastropietro P. Relationship between osteoarthrosis and osteoporosis. An experimental and clinical study. Chir Organi Mov 1995;80(02): 237-243

10 James SJ, Mirza SB, Culliford DJ, Taylor PA, Carr AJ, Arden NK. Baseline bone mineral density and boneturnover in pre-operative hip and knee arthroplasty patients. Bone Joint Res 2014;3(01): 14-19

11 Drees P, Decking J, Breijawi N, Delank S, Kreitner KF, Eckardt A. Osteoporosis and osteoarthritis-is there really an inverse relation? [in German]. Z Orthop Ihre Grenzgeb 2005;143(02):161-169

12 Simonelli C, Killeen K, Mehle S, Swanson L. Barriers to osteoporosis identification and treatment among primary care physicians and orthopedic surgeons. Mayo Clin Proc 2002;77(04):334-338

13 Korthoewer D, Chandran MEndocrine and Metabolic Society of Singapore. Osteoporosis management and the utilization of FRAX®: a survey amongst health care professionals of the AsiaPacific. Arch Osteoporos 2012;7:193-200

14 Piscitelli P, Iolascon G, Innocenti M, et al. Painful prosthesis: approaching the patient with persistent pain following total hip and knee arthroplasty. Clin Cases Miner Bone Metab 2013; 10(02):97-110

15 Bogunovic L, Kim AD, Beamer BS, Nguyen J, Lane JM. Hypovitaminosis $D$ in patients scheduled to undergo orthopaedic surgery: a single-center analysis. J Bone Joint Surg Am 2010;92(13):2300-2304

16 Zhang FF, Driban JB, Lo GH, et al. Vitamin D deficiency is associated with progression of knee osteoarthritis. J Nutr 2014;144(12): 2002-2008

17 Bergink AP, van der Klift M, Hofman A, et al. Osteoarthritis of the knee is associated with vertebral and nonvertebral fractures in the elderly: the Rotterdam Study. Arthritis Rheum 2003;49(05): 648-657

18 Aloia JF, Cohn SH, Vaswani A, Yeh JK, Yuen K, Ellis K. Risk factors for postmenopausal osteoporosis. Am J Med 1985;78(01):95-100

19 O'Connor MI. Sex differences in osteoarthritis of the hip and knee. J Am Acad Orthop Surg 2007;15(Suppl 1):S22-S25

20 Looker AC, Borrud LG, Dawson-Hughes B, Shepherd JA, Wright NC. Osteoporosis or low bone mass at the femur neck or lumbar spine in older adults: United States, 2005-2008. NCHS Data Brief 2012; (93): $1-8$

21 Shane Anderson A, Loeser RF. Why is osteoarthritis an age-related disease? Best Pract Res Clin Rheumatol 2010;24(01):15-26

22 Bonjour JP. Dietary protein: an essential nutrient for bone health. J Am Coll Nutr 2005;24(6, Suppl):526S-536S

23 Lips P. Vitamin D deficiency and secondary hyperparathyroidism in the elderly: consequences for bone loss and fractures and therapeutic implications. Endocr Rev 2001;22(04):477-501

24 Lips P, Hosking D, Lippuner K, et al. The prevalence of vitamin D inadequacy amongst women with osteoporosis: an international epidemiological investigation. J Intern Med 2006;260(03): 245-254 ( Erratum in: J Intern Med. 2007 Apr;261(4):408)

25 McAlindon TE, Felson DT, Zhang Y, et al. Relation of dietary intake and serum levels of vitamin D to progression of osteoarthritis of the knee among participants in the Framingham Study. Ann Intern Med 1996;125(05):353-359

26 Ghosh B, Pal T, Ganguly S, Ghosh A. A study of the prevalence of osteoporosis and hypovitaminosis D in patients with primary knee osteoarthritis. J Clin Orthop Trauma 2014;5(04):199-202

27 Breijawi N, Eckardt A, Pitton MB, et al. Bone mineral density and vitamin $\mathrm{D}$ status in female and male patients with osteoarthritis of the knee or hip. Eur Surg Res 2009;42(01):1-10

28 Jansen JA, Haddad FS. High prevalence of vitamin D deficiency in elderly patients with advanced osteoarthritis scheduled for total knee replacement associated with poorer preoperative functional state. Ann R Coll Surg Engl 2013;95(08):569-572

29 Domingues VR, de Campos GC, Plapler PG, de Rezende MU. Prevalence of osteoporosis in patients awaiting total hip arthroplasty. Acta Ortop Bras 2015;23(01):34-37

30 Chang CB, Kim TK, Kang YG, Seong SC, Kang SB. Prevalence of osteoporosis in female patients with advanced knee osteoarthritis undergoing total knee arthroplasty. J Korean Med Sci 2014;29 (10):1425-1431

31 Lingard EA, Mitchell SY, Francis RM, et al. The prevalence of osteoporosis in patients with severe hip and knee osteoarthritis awaiting joint arthroplasty. Age Ageing 2010;39(02):234-239

32 Labuda A, Papaioannou A, Pritchard J, Kennedy C, DeBeer J, Adachi JD. Prevalence of osteoporosis in osteoarthritic patients undergoing total hip or total knee arthroplasty. Arch Phys Med Rehabil 2008;89(12):2373-2374 